LUUPKO ŠIMUNOVIĆ, Ph.D.

E-mail: ljupko.simunovic@fpz.hr IVAN GRGUREVIĆ, B.Eng.

E-mail: ivan.grgurevic@fpz.hr

JASMINA PAŠAGIĆ ŠKRINJAR, Ph.D.

E-mail: jasmina.pasagic@fpz.hr

University of Zagreb,

Faculty of Transport and Traffic Sciences

Vukelićeva 4, HR-10000 Zagreb, Republic of Croatia
Traffic Management

Preliminary Communication

Accepted: May 10, 2009

Approved: Mar. 19, 2010

\title{
SELECTING OPTIMAL PEDESTRIAN CROSSING USING MULTI-CRITERIA DECISION-MAKING
}

\section{ABSTRACT}

Pedestrian crossings are the critical points in the traffic network that need to enable pedestrians to safely cross the road. The safety level depends on the type of pedestrian crossing. The differences between individual types of pedestrian crossings can be noted also in relation to other criteria such as the price, energy, environmental impact, accessibility, etc. Besides, various groups of users assess the quality service differently, even when this refers to the same type of pedestrian crossing. Therefore, optimal solution of a pedestrian crossing has to be selected based on a comprehensive and rational analysis and application of adequate software tools.

The selection methodology of an optimal pedestrian crossing is defined using a multi-criteria analysis. In order to view the problem as a whole, four scenarios of evaluating alternatives are foreseen. Four different groups of stakeholders: traffic experts, investors, groups of persons with disabilities and healthy persons (persons not included in the previous three stakeholder groups), who use a pedestrian crossing (according to different age, disability, perception of personal safety, etc.), assessed the importance of the offered criteria. Different groups of users have different preferences in relation to individual groups of criteria, depending on their interests and needs. One group finds the criterion of pedestrian safety the most important one, others think that finances are most important (the cost of construction), some think that accessibility is the most important issue, etc. The solutions obtained in this manner provide insight into the advantages and drawbacks of individual versions. This makes it easier for the decision-makers to select only one variant / alternative from a group of the offered solutions in compliance with the defined criteria and sub-criteria with the aim of defining an optimal pedestrian crossing for a certain spatial and traffic location.

\section{KEY WORDS}

pedestrian crossing, multi-criteria decision-making, analytical hierarchy process

\section{INTRODUCTION}

Standards for the selection of an adequate type of pedestrian crossing in the world are not unique. The selection of a crossing is mainly based on the optimisation of one criterion with a number of restrictions not taking into consideration the requirements of different stakeholders (users). Therefore function of objective $f(x)$ i.e. the solution often fails to be fair and adequate for all the traffic participants, whose interests are different and usually conflicting.

Making decision regarding the selection of the type of the pedestrian crossing, based on several criteria is the most acceptable compromise solution for all the participants. The selection is carried out through consistent evaluation of hierarchies including elements such as objectives, criteria, sub-criteria and alternatives. In this way, by comparing different system components, using quantitative techniques of decisionmaking, it is possible to select only one alternative out of several offered ones.

The work uses multi-criteria analysis (AHP - Analytical Hierarchy Process) which synthesizes the aspects of different opinions and studies the unique common result i.e. gives the answer to questions regarding the selectability of the pedestrian crossing from the aspect of the optimal characteristic of several criteria. The AHP method belongs to the class of methods for soft optimization and allows the development of a model that is used in situations when there is a number of usually conflicting criteria. It has the ability to identify and analyze the inconsistency of the decision-maker in the process of evaluating the hierarchy elements, and to provide the possibility of carrying out the sensitivity analysis during the process. The sensitivity analysis is based on the visualisation of the consequences resulting from the changes in the input data on the total alternative priorities.

In this work a model has been developed, that fully supports all the steps characteristic for the application 


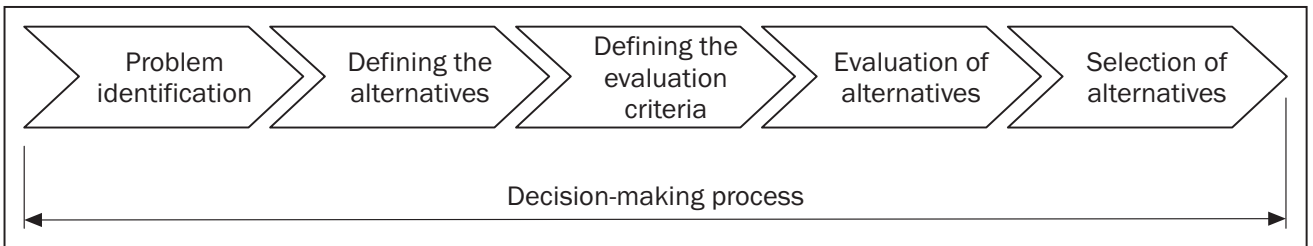

Figure 1 - Process of selecting the optimal type of the pedestrian crossing [2]

of the AHP method and the software tool known as "Expert Choice" was used.

\section{METHODOLOGY OF SELECTING OPTIMAL TYPE OF PEDESTRIAN CROSSING}

The methodology of selecting an optimal pedestrian crossing or the decision-making process has been performed in five steps presented in Figure 1. According to [2] decision-making is a set of activities that starts with the identification of the problem and ends with the selection of an alternative or a decision.

\subsection{Problem identification}

When crossing the street the pedestrians are exposed to collision with motor vehicles. According to HAK (Croatian Automobile Association) report of 24 November 2008 [32], the number of the fatalities per million citizens, on pedestrian crossings in Croatia was 28 , in Slovenia 18 , whereas in Italy this number was 13 , which means that the number of fatalities in Croatia is double the number in Italy, i.e. one and a half times larger than in Slovenia. Because of potential threats that occur on pedestrian crossings, and also because of standstills in traffic the problems of pedestrian crossings are always of topical interest. Due to the complexity of the problems that occur at places where the pedestrians cross the road, the selection of the optimal type of the pedestrian crossing has been carried out on the basis of systemic analysis, with participation of different groups of users who have scientifically, professionally, and objectively analyzed the problem in order to balance the opposites between the economic and environmental requirements, as well as the requirements of the user groups themselves. This process is time-consuming and complex, and therefore usually not carried out, which eventually results in a large number of accidents and high level of stress while crossing the road, all the way to the failure of using these facilities.

\subsection{Defining the alternatives}

The work was limited to four types of pedestrian crossings i.e. road passages that are usually used in the Republic of Croatia, and these are:
- A1 - marked pedestrian crossings without traffic lights (further in the text the term zebra crossing is used),

- A2 - marked pedestrian crossings with traffic lights (further terms that are used in the text are signal controlled crossings),

- A3 - pedestrian passages: overpass,

- A4 - pedestrian passages: underpass.

The terms used for pedestrian crossings have not been harmonised with the terminology offered by the Act on Road Traffic Safety [9] which for this level of research is not of significance, since the terms as such have been widely accepted and are unambiguously identifiable among the respondents i.e. users of crossings/passages. Generally, all the mentioned types of pedestrian crossings/passages represent alternatives and are designated by codes A1 to A4. The knowledge of advantages and drawbacks of every alternative is necessary for the selection and classification of criteria as well as pondering of the selected criteria.

\subsection{Defining the alternative evaluation criteria}

Defining and selection of the criteria that will affect the efficiency of the made decisions is a complex and sensitive task, due to the need to consider the problem and all the key parameters integrally. For the selection of the optimal pedestrian crossing i.e. precise ranking of the alternatives, adequate number of criteria have been introduced, that were classified into four main groups. The criteria have been further broken down into subcriteria as presented here:

I. Safety Criterion $\left(\mathrm{k}_{1}\right)$

a. Sub-criterion: Driving speed;

b. Sub-criterion: Traffic volume/intensity;

c. Sub-criterion: Length of the pedestrian crossing (road width).

II. Energy Criterion $\left(\mathrm{k}_{2}\right)$

III. Price Criterion $\left(\mathrm{k}_{3}\right)$

a. Sub-criterion: Price of design;

b. Sub-criterion: Price of construction;

c. Sub-criterion: Price of maintenance.

IV. Criterion: Other $\left(\mathrm{k}_{4}\right)$
a. Sub-criterion: Noise;
b. Sub-criterion: Environmental impact;
c. Sub-criterion: Comfort;
d. Sub-criterion: Access for the disabled. 


\begin{tabular}{|c|c|c|c|c|c|c|c|}
\hline Authors & $\begin{array}{l}\text { Data from } \\
\text { the year }\end{array}$ & $30 \mathrm{~km} / \mathrm{h}$ & $50 \mathrm{~km} / \mathrm{h}$ & $70 \mathrm{~km} / \mathrm{h}$ & \multirow{9}{*}{$\begin{array}{c}15 \% \\
32 \mathrm{~km} / \mathrm{h} \\
20 \mathrm{MPH}\end{array}$} & \multirow[b]{4}{*}{$45 \%$} & $85 \%$ \\
\hline Anderson et al. (1997) & 1978 & $8 \%$ & $85 \%$ & $100 \%$ & & & \multirow{8}{*}{$\begin{array}{l}65 \mathrm{~km} / \mathrm{h} \\
40 \mathrm{MPH}\end{array}$} \\
\hline Ashton (1982) & 1965-1979 & $\sim 5 \%$ & $\sim 45 \%$ & 95\% & & & \\
\hline Pasanen (1992) & 1965-1979 & $6 \%$ & $40 \%$ & $94 \%$ & & & \\
\hline Yaksich (1964) & $1958-1963$ & $\sim 22 \%$ & $\sim 65 \%$ & $100 \%$ & & \multirow{5}{*}{$\begin{array}{l}50 \mathrm{~km} / \mathrm{h} \\
30 \mathrm{MPH}\end{array}$} & \\
\hline Cuerden et al. (2007) & $2000-2007$ & $\sim 2 \%$ & $\sim 12 \%$ & 33\% & & & \\
\hline Davis (2001) & 1965-1979 & $1 \%$ & $7 \%$ & $51 \%$ & & & \\
\hline Hannawald \& Kauer (2004) & $1991-2003$ & $4 \%$ & $14 \%$ & $39 \%$ & & & \\
\hline Oh et al. (2008b) & 2003-2005 & $7 \%$ & $34 \%$ & $77 \%$ & & & \\
\hline
\end{tabular}

Figure 2 - Percentage of fatalities among pedestrians at certain driving speeds according to different sources [ a.) 16, 17, 18, 19, 20, 21], [ b.) 22]

\section{Description of criteria and sub-criteria}

\section{Criterion $\mathrm{k}_{1}$ : Safety}

Safety is a condition in which a person can normally perform their functions i.e. normally cross a pedestrian crossing, with the process not being disturbed nor degraded due to various threats and dangers, adapted according to [24], [25].

The estimate of risk is a procedure of evaluating the probability of events that represent possible danger and threat to persons crossing the road. As possible dangers, the driving speed, traffic volume/intensity and the road width have been analyzed. Personal safety of a pedestrian against vandalism i.e. violence is analyzed in Criterion $\mathrm{k}_{4}$ Other.

\section{a) Sub-criterion: Driving speed}

If motorists drive at high speeds along the roads, the pedestrian cannot properly estimate the moment at which the vehicle will reach the pedestrian crossing i.e. the point of intersection between the paths of the vehicle and the pedestrian, and the motorist is not able to stop the vehicle on time. The greater the difference in the speed between the pedestrian and the vehicle, the greater is the danger for the pedestrian.
Figure 2 shows the percentages of fatalities among the pedestrians at certain driving speeds according to different sources.

According to the authors Teichgräber, Ashton, Waltz and others, the risk of the pedestrian getting killed on a pedestrian crossing at a speed of $30 \mathrm{~km} / \mathrm{h}$ is less than $10 \%$, at a speed of $50 \mathrm{~km} / \mathrm{h}$ it is about $50 \%$, whereas at a speed of $60 \mathrm{~km} / \mathrm{h}$ almost every conflict with a motor vehicle proves to be fatal (according to Waltz et al.), and according to Teichgräber and Ashton the risk ranges between $70 \%$ and $80 \%$ (detailed data are presented in Figure 3).

\section{b) Sub-criterion: Traffic volume/intensity}

If the traffic intensity often results in situations in which the time gap between the approach of two succeeding vehicles is shorter than the time required to cross the road, the method of stopping the vehicle has to be applied in order to perform the crossing. At these places the pedestrian crossing - zebra is usually constructed.

If traffic is of higher intensity resulting in even scarcer occurrences of suitable intervals to cross the road, the pedestrians lose patience and recklessly step onto

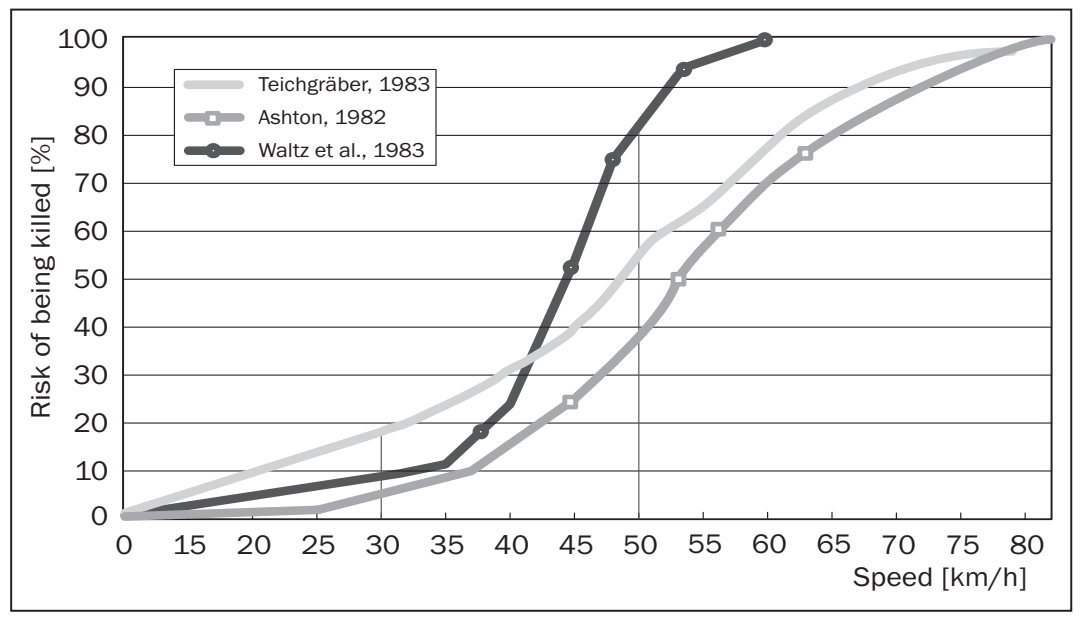

Figure 3 - Average value of pedestrian fatalities on pedestrian crossing due to conflict with motor vehicle [12], [13], [14] 


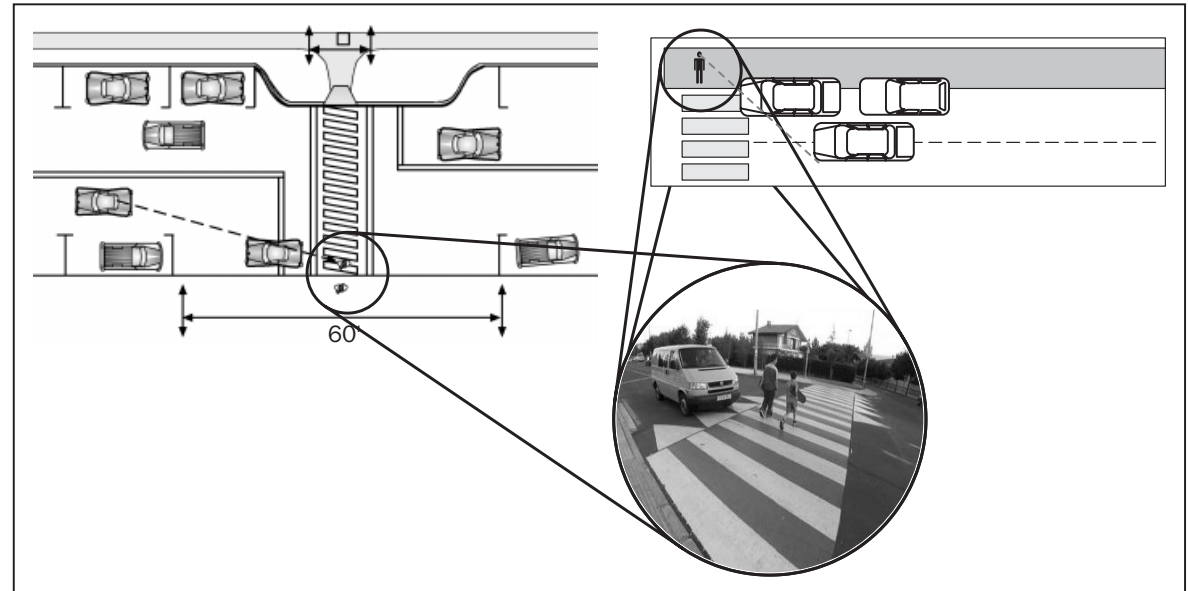

Figure 4 - The influence of the length of the pedestrian crossing on the safety of pedestrians

the roadway. The consequences of such actions may be catastrophic and in such situations zebra crossings do not usually match the needs and a signalized crossing needs to be constructed.

Should traffic lights cause very long queues of vehicles, and pedestrian waiting time exceed the limit of patient waiting (30 seconds) [15], [27], then the pedestrian crossings are grade-separated, i.e. the problem is solved by constructing overpasses or underpasses, i.e. separating the pedestrians and vehicles into different levels.

c) Sub-criterion: Length of the pedestrian crossing

The length of the pedestrian crossing is in multiple correlation with traffic safety. The crossing time using a longer pedestrian crossing means longer stay of the pedestrian on the roadway and higher risk of getting injured. On a multi-lane road the vehicles moving along the right kerb often obscure the view of vehicles that move along the farther lane. This phenomenon is especially noted in cases when small children want to cross the street and the motorists fail to notice them on time (Figure 4). This leads to accidents even when the pedestrians cross the street in a regular manner, and the motorists drive carefully. This problem is especially emphasized in the vicinity of schools [3].

\section{Criterion k2: Energy}

Energy is a measure for the effort invested by a pedestrian to cross the road moving between two points.
The limited energy resources available to a human act in a self-regulating manner, and this means that the human tends to avoid ascents, wishes to take the shortest route to the destination, match the walking speed and the energy consumption, etc. From the aspect of energy the humans spend least energy when walking down the stairs or ramp, due to gravity, then on a level surface, and they spend most energy when climbing the stairs. According to Bovy the ratio of energy consumption when crossing the at-grade road, overpass and underpass is 1:6:9 [24]. Such relation of energy consumption obtained by Bovy results not only from the climbing the stairs but also because of the longer path walked by a pedestrian taking the underground or aboveground path, as presented in Figure 5.

The height of the overpass stairs is in the function of the free road profile which is $4.5 \mathrm{~m}$, and the height of the underpass stairs is somewhat smaller and equal to the height of the free profile of the pedestrian $(2.5 \mathrm{~m})$ increased by the roadway height [28]. Depending on the length of the underpass, the height of the underpass, and thus also of the stairs is usually greater. The total path walked by the pedestrian consists of the length of the underpass i.e. overpass and the lengths of the ramps i.e. stairways. The pedestrian underpasses, and especially overpasses due to long ramps (stairways), are not the best solutions for urban environments. Therefore, in Croatia, the overpasses

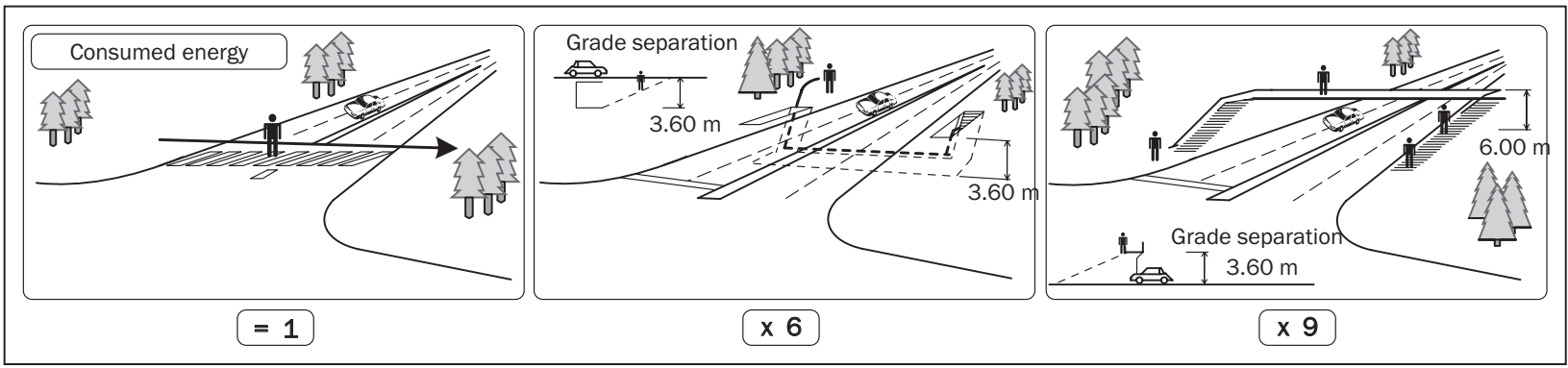

Figure 5 - Energy consumption while crossing the road [24] 
are mainly planned and designed in the vicinity of stations of public urban transit.

It is assumed in the paper that there are no spatial limitations for the construction of pedestrian crossings and that the construction conditions for all the studied alternatives are the same.

\section{Criterion $\mathrm{k}_{3}$ : Price}

Price is generally defined as a monetary expression for the value of a product or service. In practice, the price is the amount of money which is paid when purchasing a product or service calculated for the item of product or service. There are different approaches in pricing for different market conditions, ranging from full competition to monopoly. The factors that affect the prices are numerous and diverse [6].

In forming the criteria of prices for pedestrian facilities, the prices i.e. costs of design, construction and maintenance have been taken into consideration and studied as separate subcriteria.

\section{Criterion k4: Other}

For the criterion Other there are no exact numerical indicators which may be quantified and therefore it is impossible to estimate the actual values of individual criteria. The criterion Other serves exclusively as an additional assistance to the decision-maker, since it shows the importance i.e. value of individual additional subcriteria that may tilt the balance for the potential user in case previous criteria were counterbalanced.

The criterion Other is classified into subcriteria: traffic noise, environmental impact, comfort and access to persons with disabilities (considered ergonomic factors).

\section{a) Sub-criterion: Noise}

Noise is one of the main causes that reduce the quality of living in urban environments. It occurs as consequence of the vehicle engine operation and interaction of the vehicle pneumatics and the roadway surface as well as the passage of vehicle through the medium (air). Out of all the noise sources the highest percentage is accounted for by traffic-generated noise, about $81 \%$. Out of the total of $81 \%$ the biggest source of noise is road traffic and it accounts for about $50 \%$, rail traffic $18 \%$ and air traffic $13 \%$ [29]. The costs incurred as consequence of traffic-generated noise range between 0.2 and $2 \%$ GDP [30].

On zebra crossings and crossings with traffic lights, the pedestrians are at the very source of noise, in the vicinity of vehicles, whereas in underpasses and overpasses they are much better protected. Therefore, one may say that the noise imission to which the pedestrians are exposed is usually equal to the emission generated by motor vehicles. The influence of noise is greater the closer the vehicles are to the pedestrian crossing and the larger their number. This influence is most expressed in peak traffic when there are most vehicles on the road, but pedestrians as well. The maximally permitted noise level imissions in open spaces according to [10] shall not exceed the equivalent noise level of $50 \mathrm{~dB}$ at night, i.e. $65 \mathrm{~dB}$ during day.

\section{b) Sub-criterion: Environmental impact}

The subcriterion Environmental impact considers the negative impacts of the construction of the pedestrian crossing on the environment, permanent destruction of the environment, change of microclimatic circumstances, changes of the landscape (disturbance of the ecological balance) and negative impacts during construction (transport, excavations, etc.).

\section{c) Sub-criterion: Comfort}

This subcriterion estimates the comfort of the pedestrian crossing from the user's aspect. In estimating the comfort the user takes into consideration several factors:

- aesthetics that we experience as something that is "pleasant to the eye "i.e. nice or ugly or something that is between these two extreme notions (due to the low movement speed the pedestrian receives in the same period of time a much larger number of information than the motorists, so that the attractiveness and the beauty of the environment perceived by the pedestrian is very important),

- coherency of space (in underpasses where the pedestrian is separated from the external world and orientation points, logic communication and harmony are required as well as clear signalling that will provide guidance to the destination), and

- feeling of personal protection primarily against vandalism and criminal actions.

The last factor is among the most important ones and can be stimulating or discouraging for walking. Therefore, the pedestrian facilities have to be designed in such a way that they are available for usage 24 hours a day (24/7/365). Otherwise, pedestrians would be discouraged from walking there. Very often the reasons for the under-usage of under- and overpasses are found in the previously stated facts.

Night is universally recognizable as potential danger and this alone discourages pedestrians from walking. The feeling of pedestrian comfort may be influenced by good lighting, as well as a larger number of pedestrians. Therefore, people often prefer moving through more active and "busier" areas. The present pedestrians are considered as "eyes of the street" and as such additionally increase safety.

The stimulation of using the pedestrian areas / facilities is possible not just by the usage of good lighting and presence of a larger number of pedestrians, but rather also by the usage of a control system using cameras (CCTV), installation of SOS buttons on mobile phones or through the offer of other advanced solutions in the ITS (Intelligent Transport Systems) domain.

d) Sub-criterion: Access for the disabled

Access for the disabled means that the pedestrian facility is constantly accessible for the mentioned 
group of pedestrians, i.e. that they may use it when they need it.

It is estimated that there are about 500 million persons with disabilities worldwide, which is about a tenth of the total population, whereas as much as one third are accounted for by children. According to [33] in the Republic of Croatia there are 429,421 persons with disabilities, out of which 29,952 live in Zagreb. The number of blind persons in the Republic of Croatia amounts to about 5800, whereas the number of the poor-sighted persons is 2 to 3 times greater. It is estimated that in the Republic of Croatia there are about 12,000 persons with severest hearing impairment and about 60,000 with a somewhat lighter impairments. There are 1118 completely deaf persons and 3800 hearing-impaired persons registered in Zagreb. The loss of hearing is not as significant a barrier in traffic as the loss of sight. Some other groups of users certainly should not be neglected, that may have difficulties in accessing the pedestrian facilities such as senior and disabled persons (there are $16.6 \%$ of persons over 65 years of age in Croatia [33]), mothers with perambulators, pregnant women, etc. The given numbers speak about the significant share of persons who are sufficiently considered when selecting the optimal pedestrian crossing. If pedestrian facilities are designed so as to be accessible to persons who need help and persons with disabilities, then they will be accessible also for the healthy categories of pedestrians regardless of their age and gender. The approach to overpasses and underpasses to the mentioned group of pedestrians can be made easier by the construction of adequate ramps and lifts.

\section{MULTI-CRITERIA DECISION- MAKING MODEL}

Multi-criteria decision-making allows optimization according to several criteria thus improving the quality of the decision-making process. The process represents the optimization of the function of objective on a set of possible solutions, and these solutions are evaluated, compared and ranked by the decision-maker.

AHP is a multi-criteria technique of breaking down a complex problem into a hierarchy, with the objectives being at the top, and the criteria, subcriteria and alternatives at lower levels, as presented in Figure 6 . The hierarchy created in such a way represents the initial

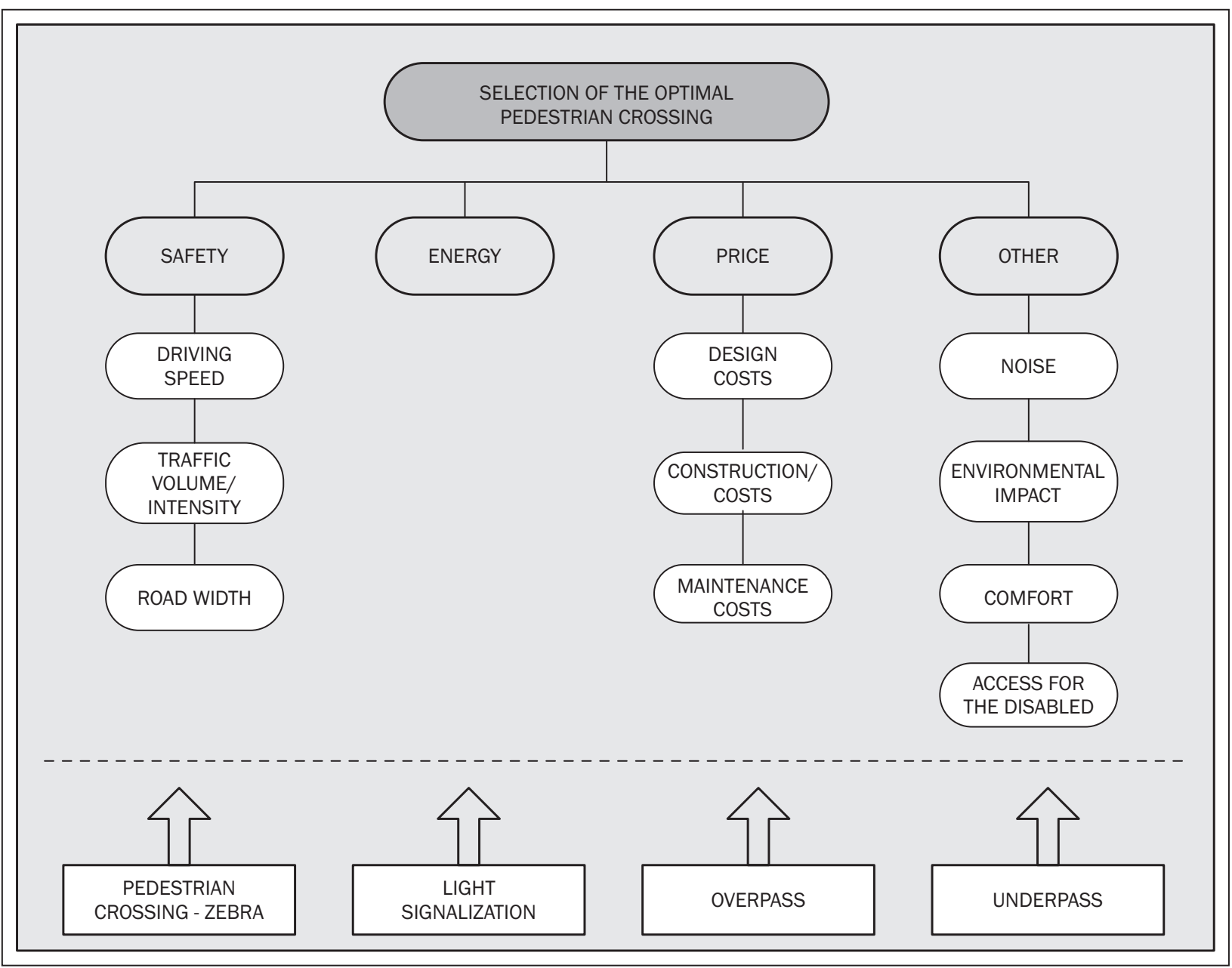

Figure 6 - Scheme of multi-criteria model for the selection of optimal pedestrian crossing 
decision-making model, followed by the top-down evaluation of the hierarchy elements.

The usage of AHP allows the decision-makers to set the priorities and make decisions in case when it is necessary to take into consideration also the quantitative and qualitative characteristics (non-comparable units of measures).

\section{CRITERIA EVALUATION PROCESS}

The process of criteria evaluation has been developed by comparing the criteria pairs according to four scenarios. Scenario 1 represents the proposal of a group of ten traffic experts, scenario 2 is the proposal of ten investors (construction entrepreneurs), scenario 3 has been proposed by ten persons with disabilities out of which six persons are in wheelchairs and four are blind (persons with special needs), whereas scenario 4 includes a hundred "healthy" persons (pedestrians - refers to persons who have not been included in the previous three groups). During the survey of the healthy persons the attention was paid to the age of the respondents as well as the possible epistemological difficulties.

When the evaluation process includes several individuals, the decision of the group may be brought by consensus or by processing individual evaluations. The processing of individual evaluations is a less demanding way of reaching a solution. There are several ways of aggregating the evaluations and the usual ones are AIP (Aggregating Individual Priorities) and AIJ (Aggregating Individual Judgements). The AIP method is based on the synthesis of individual final priorities, and then merging of individual priorities into a final priority. The arithmetic or geometric means may be used as the calculation procedure. The aggregation of individual judgements or AIJ is a method which is used to gather individual evaluations for every set of pairs to be compared, so that every gained priority vector is the result of the group decision. The usual computer pro- cedure that performs the merging of individual evaluations is the geometric mean [7].

The data from the participants were collected using a survey method with Saaty scale of importance for the comparison of elements. A part of the results obtained by the survey is presented in Figure 7 . The Figure show the comparison of criteria pairs $k 3$ and k4 (price and energy) from the aspect of the investor (scenario 2) and persons with disabilities (scenario 3), leaving out other comparisons. In order to calculate the average grade for the group the geometric mean was used.

Ten surveyed investors consider the criterion of price much more important than the criterion of energy. The preference of price over energy, from the investor's viewpoint, amounts to 5.4774. Preference of energy over price amounts to 5.7645 , which means that the persons with disabilities prefer, i.e. consider the criterion of energy much more important than the criterion of price.

All the criteria are not equally important, and relative importance of the criteria results from the preferences of the decision-maker which is related to their system of values. Based on the aggregate grades of a group, pairwise comparison matrices are obtained. The matrices of aggregate grades of pairwise comparisons are input into the software tools.

\section{PROCESS OF ALTERNATIVES EVALUATION}

The process of alternatives evaluation has been performed by comparing the pairs of criteria which are assigned a combined grade of the stakeholder group, according to all four scenarios. The higher the grade assigned to a criterion, the higher its influence on the final grade. The method of assigning values to single criteria results in a general model for the selection of the optimal pedestrian crossing. Depending on the studied group of stakeholders (experts, investors, the disabled, healthy persons) it is possible to adapt

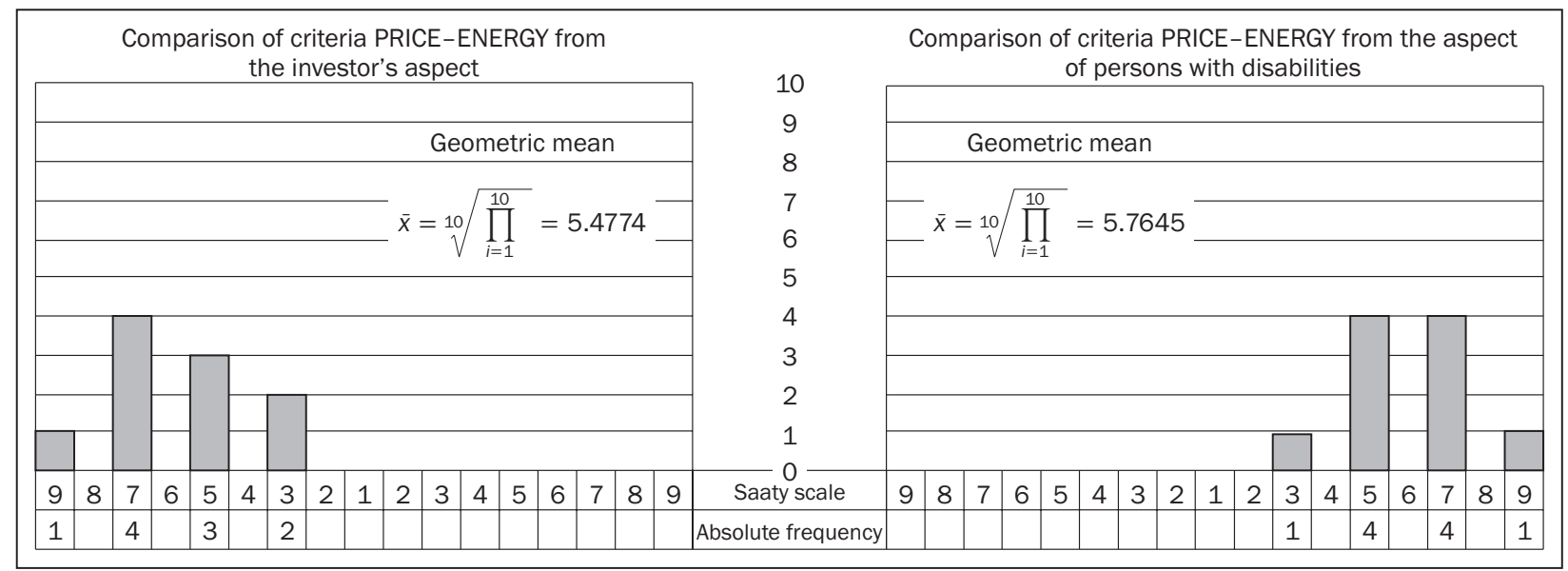

Figure 7 - Comparison of price - energy criteria from the investor's aspect and from the aspect of persons with disabilities 


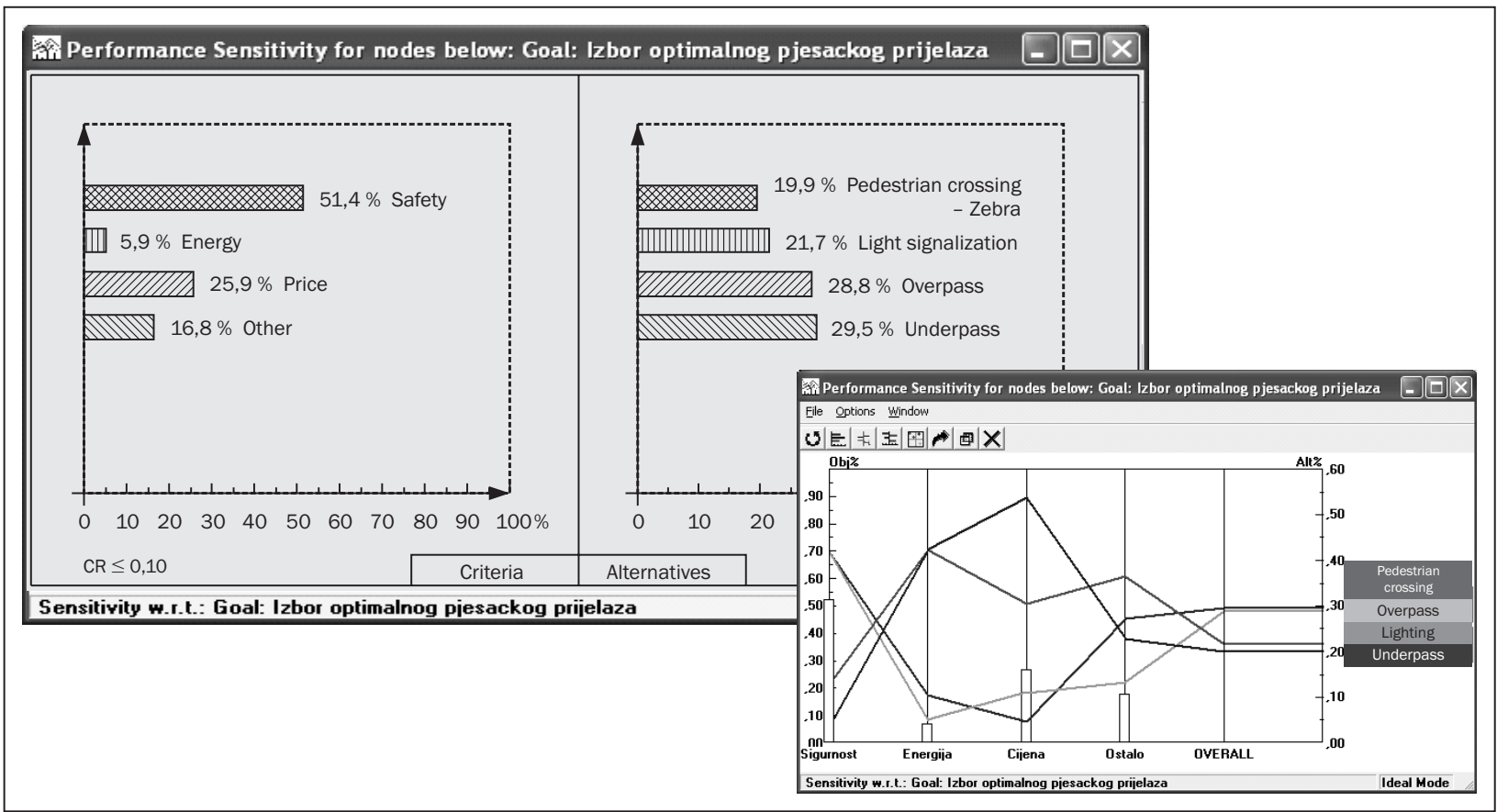

Figure 8 - Selection of the optimal pedestrian crossing and performance sensitivity from the aspect of Experts (scenario 1) the model so that some criteria are highlighted, that are essential to individual type of the user, and to leave out those that are not of importance in selecting the optimal pedestrian crossing. Figure 8 shows the results obtained according to the evaluation of a group of Experts (scenario 1) and the performance sensitivity according to the simulation model using the software tools "Expert Choice". This group gives priority, with very small advantage, to the underpass, and the highest pondered value is given to the traffic safety.
Regarding traffic safety, the underpass and overpass are the safest solutions. Regarding energy and price the best solutions are the zebra crossings and crossings with traffic lights. According to the criterion Other the best solution is the crossing with traffic lights.

Figure 9 shows the results of selecting the optimal pedestrian crossing from the investors' aspect (scenario 2) and the performance sensitivity.

The investor finds the zebra crossing the best solution, and underpass the worst solution. The criterion of price is assigned the highest weight.

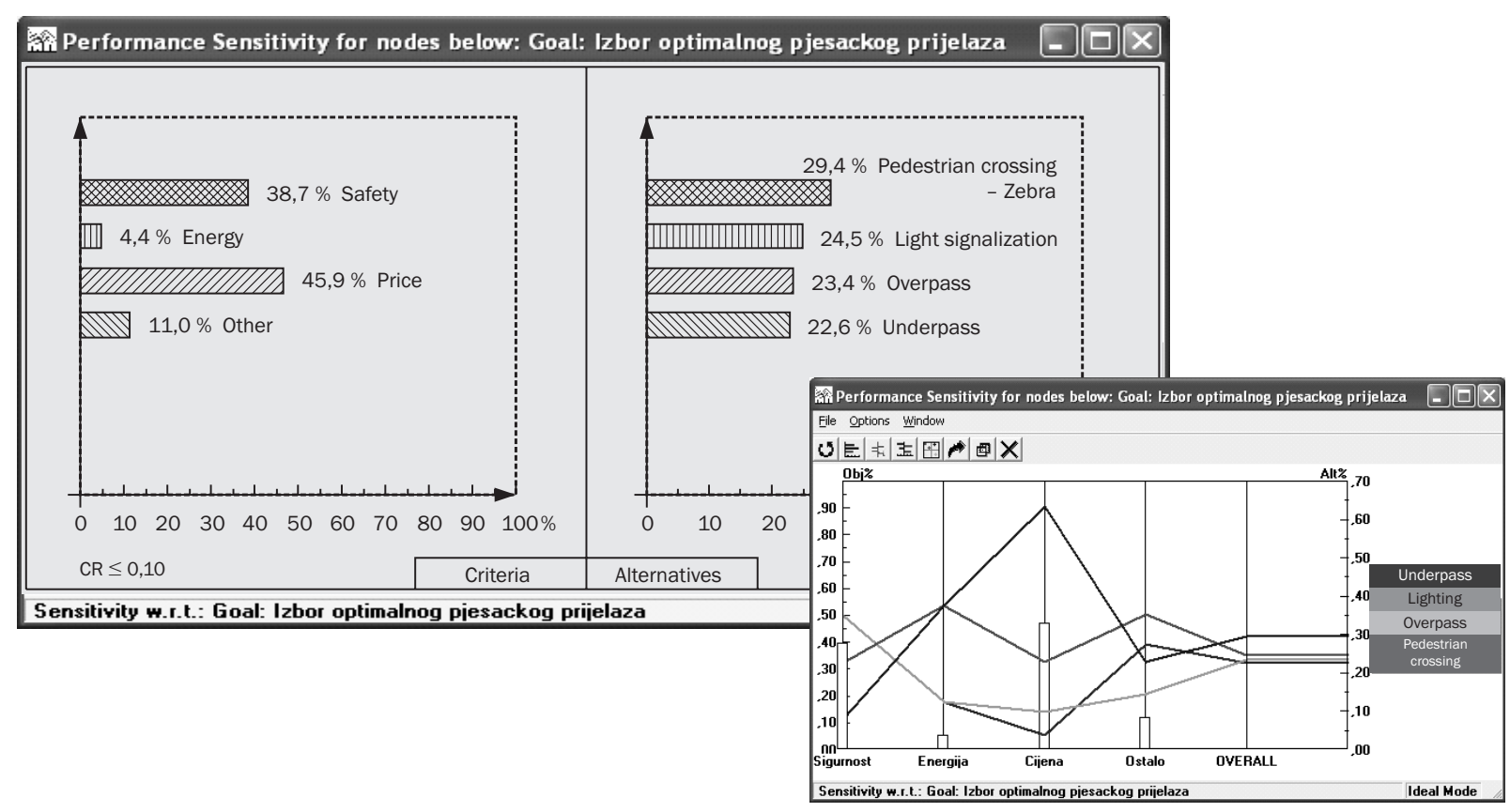

Figure 9 - Selecting optimal pedestrian crossing and performance sensitivity from the aspect of Investors (scenario 2) 


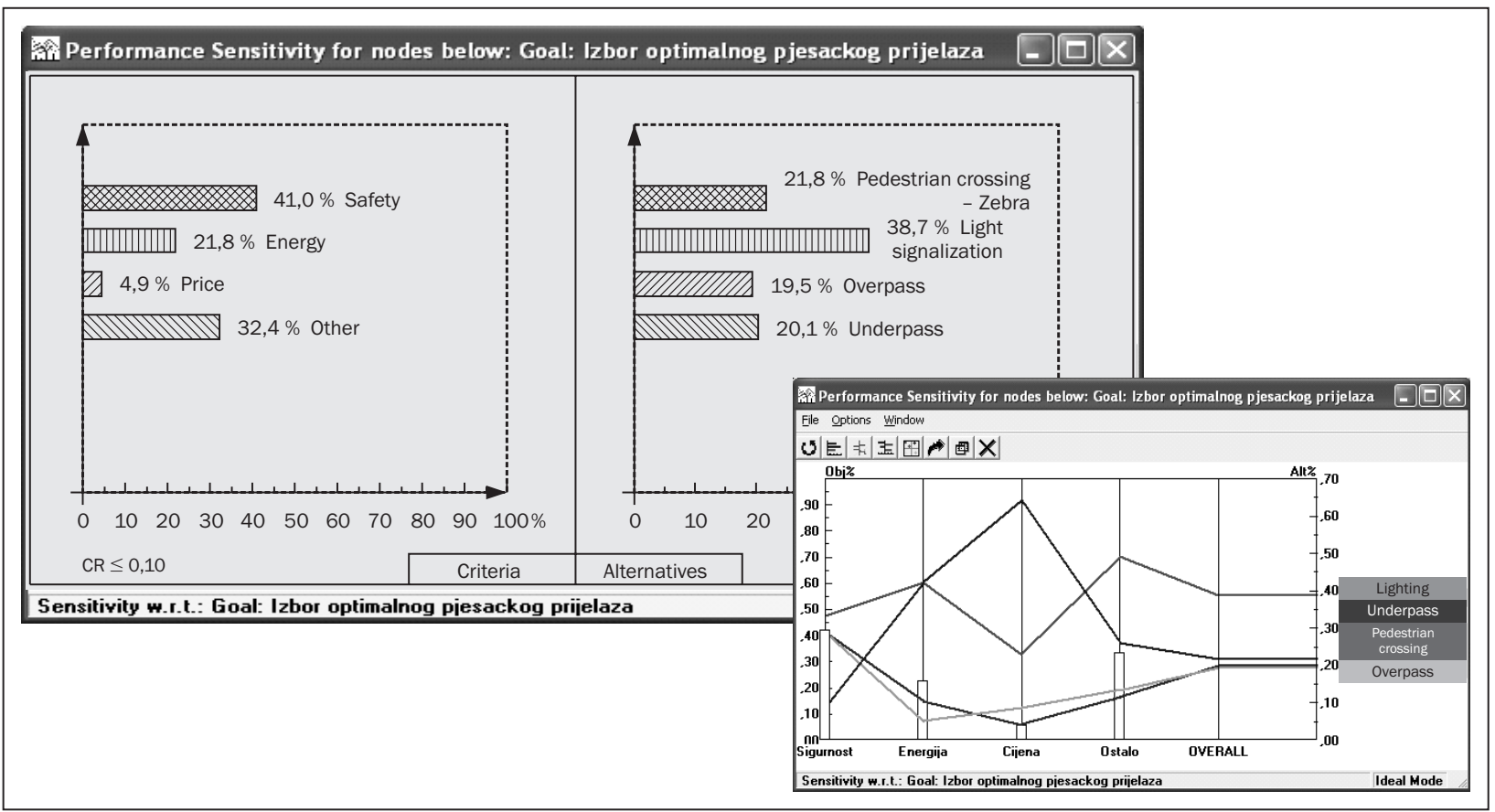

Figure 10 - Selection of optimal pedestrian crossing and performance sensitivity from the aspect of Persons with disabilities (scenario 3)

Figure 10 shows the results of selecting the optimal pedestrian crossing from the aspect of Persons with disabilities (scenario 3) and the performance sensitivity.

Pedestrian crossing with light signalization (traffic light) has proven to be the best solution according to the selection of the Persons with disabilities. The persons with disabilities render much greater weight to the criteria of energy and other compared to other surveyed respondents, which is only understandable.
It is interesting to note that the disabled persons gave priority to traffic lights over underpass and overpass regarding all the criteria. Regarding the criterion Price, zebra is preferred over traffic light, and regarding energy consumption the obtained data are identical.

Figure 11 shows the results of selecting the optimal pedestrian crossing from the aspect of Healthy persons (average users), scenario 4, and the performance sensitivity.

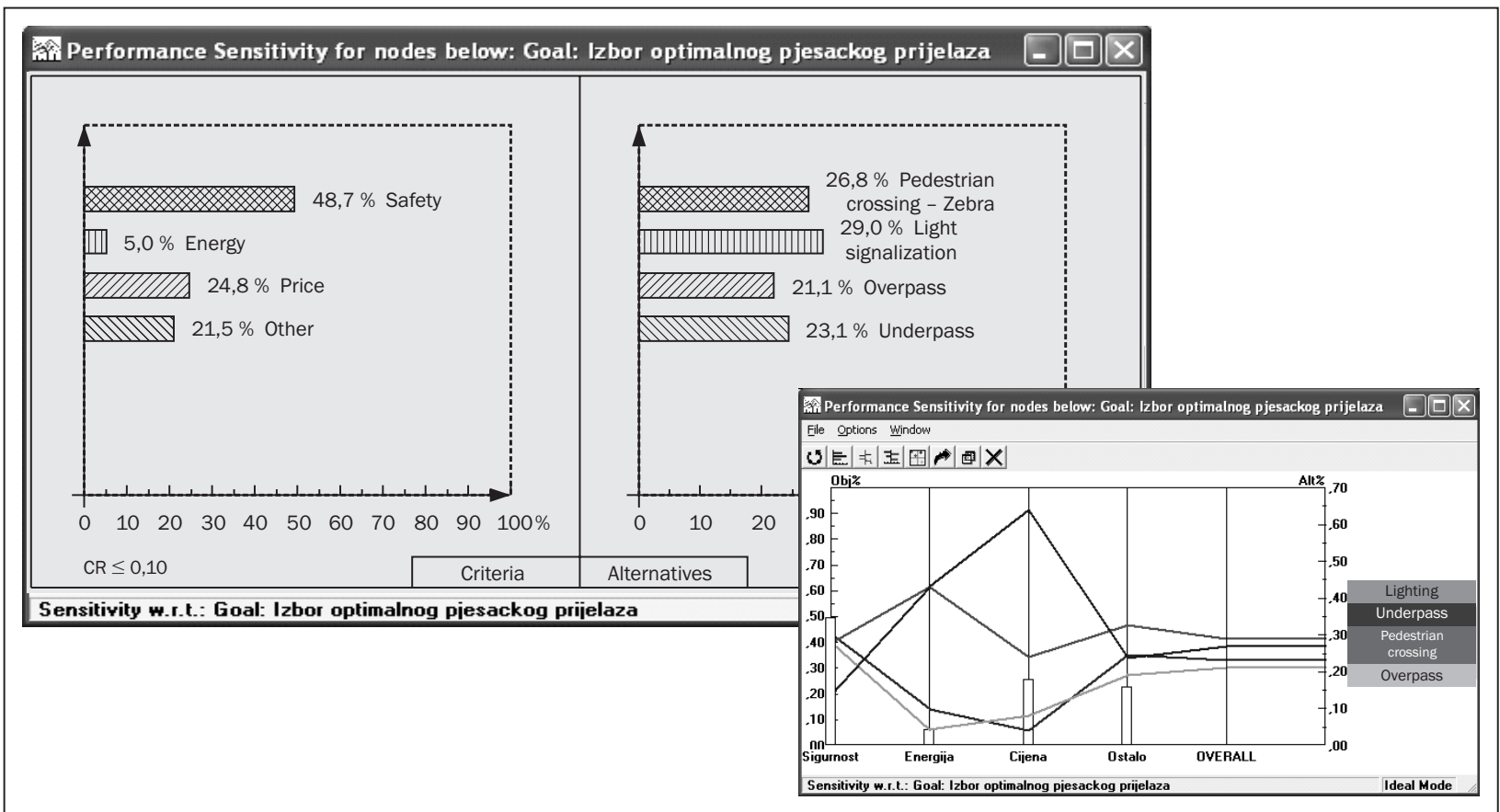

Figure 11 - Selecting optimal pedestrian crossing and performance sensitivity from the aspect of Healthy persons (scenario 4) 
Like the persons with disabilities, healthy persons (pedestrians) have selected as the best variant the signal-controlled pedestrian crossing. The basic difference between these two scenarios is that the healthy persons assess approximately equally all the alternatives, unlike persons with disabilities who give clear priority to the traffic lights over other types of pedestrian crossings.

The ratio of consistency of the obtained results in each matrix (for the defined ratios of criteria weights and priorities of alternatives) is less than 0.10 (CR $\leq 0.10)$.

\section{SELECTION OF ALTERNATIVES}

The application of systemic engineering tools enables an integral and rational analysis of the validity and sensitivity of the alternatives, along with the proposal of the best solutions based on the preferences of different groups.

According to scenario 1 the Experts have given the highest weight to Criterion $\mathrm{k}_{1}$ - Safety, which gives the highest priority of alternative $A_{4}$ - underpass.

In scenario 2 the Investors have given the highest weight to Criterion $k_{3}$ - Price, so that alternative $A_{1}$ - Zebra crossing got the highest priority.

According to scenario 3, the Persons with disabilities have given the highest preference to the traffic lights (alternative $A_{2}$ ).

According to the selection of the Healthy persons (scenario 4) the signal-controlled pedestrian crossing (alternative $\mathrm{A}_{2}$ ) received the highest priority.

Healthy pedestrians and persons with disabilities assigned the highest weight to the value of criterion $\mathrm{k}_{1}$ - traffic safety. The lowest variability grade in assigning a unique grade by the users was achieved in case of the pedestrian crossing - zebra and the signal-controlled pedestrian crossing (with traffic lights), which means that the mentioned alternatives represent the best compromise for all the analysed stakeholders. The comparison of the ranking of alternatives according to all four studied scenarios is given in Figure 12.

\section{CONCLUSION}

The methodology of selecting a pedestrian crossing proposed by the carried out research is comprehensive and based on the influence of the decisions made by various stakeholder groups who have different preferences regarding the defined groups of crite-

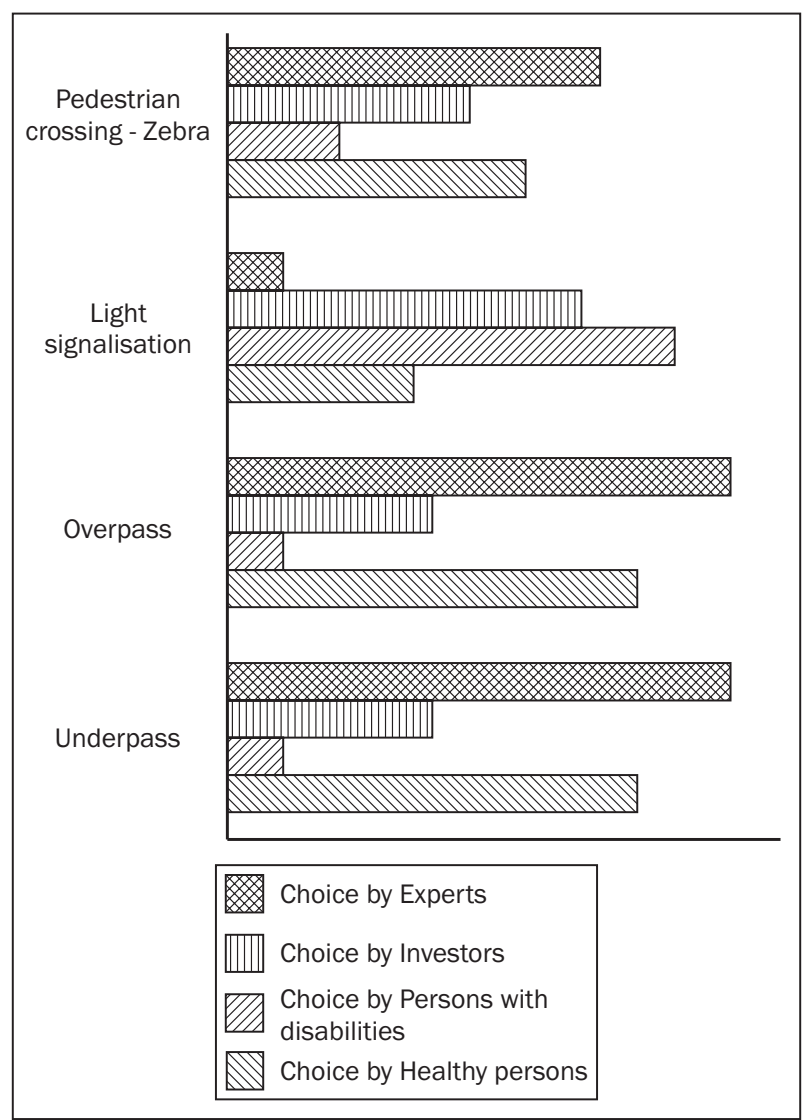

Figure 12 - Comparison according to the scenarios

ria. The sensitivity test has made it possible to test the influences of individual alternatives on the function of objective and the selected criteria. The criteria here have quantitative and qualitative characteristics.

The appropriate software tools for multi-criteria decision-making have been used to calculate the weight values of criteria and alternatives for the selection of the optimal pedestrian crossing.

According to different scenarios, and depending on the surveyed stakeholder group the results have been obtained that serve as support to decision-makers.

The defined methodology, research results and the carried out sensitivity test for each of the set alternatives have enabled an insight and testing of the future scenarios before these are applied in practice when selecting a pedestrian crossing. In planning the pedestrian crossings one should take into consideration all the specific characteristics which depend on a certain location in space, programs of measures to improve the condition in space and the maintenance plan and the traffic signalisation reconstruction. 
Dr. sc. LUURO ŠIMUNOVIĆ

E-mail: ljupko.simunovic@fpz.hr

IVAN GRGUREVIĆ, dipl. ing.

E-mail: ivan.grgurevic@fpz.hr

Dr. sc. JASMINA PAŠAGIĆ ŠKRINJAR

E-mail: jasmina.pasagic@fpz.hr

Sveučilište u Zagrebu, Fakultet prometnih znanosti

Vukelićeva 4, 10000 Zagreb, Republika Hrvatska

\section{IZBOR OPTIMALNOG PJEŠAČKOG PRIJELAZA VIŠEKRITERIJSKIM ODLUČIVANJEM}

\section{SAŽETAK}

Pješački prijelazi su kritična mjesta u prometnoj mreži koja trebaju omogućiti siguran prelazak pješaka preko cestovne prometnice. Razina sigurnosti ovisi o vrsti pješačkog prijelaza. Razlike između pojedinih vrsta pješačkih prijelaza uočljive su i u odnosu na druge kriterije kao što su cijena, energija, utjecaj na okoliš, pristupačnost, itd. Osim toga različite skupine korisnika drugačije ocjenjuju kvalitetu usluge čak i kada se radi o istoj vrsti pješačkog prijelaza. Stoga su za izbor optimalnog rješenja pješačkog prijelaza nužni sveobuhvatna i racionalna analiza te primjena odgovarajućih programskih alata.

Metodologija izbora optimalnog pješačkog prijelaza definirana je uz pomoć višekriterijske analize. Kako bi se problem sagledao u cjelini predviđena su četiri scenarija vrednovanja alternativa. Četiri različite interesne skupine korisnika: prometni eksperti, investitori, skupine osoba s invaliditetom i zdravih osoba (osobe koje nisu obuhvaćene $u$ prethodne tri interesne skupine) koje koriste pješački prijelaz (prema različitoj životnoj dobi, invalidnosti, percepciji osobne sigurnosti, itd.), ocjenjivale su važnost ponuđenih kriterija. Različite skupine korisnika imaju različite preferencije $u$ odnosu na pojedine grupe kriterija, ovisno o svojim interesima i potrebama. Jednima je najvažniji kriterij sigurnost pješaka, drugima financije (cijena izrade), trećima pristupačnost, itd. Na taj način dobivena rješenja pružaju uvid u prednosti i nedostatke pojedinih varijanti. Donositelju odluke olakšava se odabir samo jedne varijante/alternative iz skupa ponuđenih rješenja sukladno definiranim kriterijima i potkriterijima u cilju definiranja optimalnog pješačkog prijelaza za određenu prostorno-prometnu lokaciju.

\section{KLUUČNE RIJEČI}

pješački prijelaz, višekriterijsko odlučivanje, analitički hijerarhijski proces

\section{LITERATURE}

[1] McLean, A.J., Anderson, R.W.G., Farmer, M.J.B., Lee, B.H. and Brooks, C.G.: Vehicle travel speeds and the incidence of fatal pedestrian collisions, Canberra: Federal Office of Road Safety: Report CR 146, 82p., 1994

[2] Dunham, R.B., Pierce, J.L.: Management, Scott Foresman and Company, Glenview, Illinois-London, England, 1989

[3] Šimunović, Lj., Jerneić, B., Fuček, Z.: Povećanje sigurnosti pješaka prilagođivanjem regulativnih elemenata na pješačkim prijelazima, $11^{\text {th }}$ International Symposium: "Promet u gradovima" (Traffic in the Cities)
/ Rotim, Franko (ed.), Zagreb: Hrvatsko znanstveno društvo za promet, pp. 143-147, 2003

[4] Saaty, T.L.: Decision making for leaders - The Analytic Hierarchy Process for Decisions in a Complex World, RSW Publications, Pittsburgh, 2001

[5] Vargas, L.G.: An overview of the Analytic Hierarchy Process and its applications, European Journal of operational Research, 48, pp. 2-8, 1990

[6] Bošnjak, l.: Tehnologijski (HI-TECH) marketing, Faculty of Transport and Traffic Sciences, Zagreb, 1996.

[7] Forman, E., Peniwati, K.: Aggregating individual judgments and priorities with the Analytic Hierarchy Process, European Journal of Operational Research, Vol. 108, Issue 1, 1998

[8] Highway Capacity Manual 2003: Transportation Research Board, Washington, D.C., 2003, http://www. trb.org/ (15 Feb. 2009)

[9] Narodne novine službeni list RH (Official Gazette), No. $67 / 2008$, Zakon o sigurnosti prometa na cestama, http://narodne-novine.nn.hr/ (17 Feb. 2009)

[10] Narodne novine službeni list RH (Official Gazette), No. 145/2004, Pravilnik o najvišim dopuštenim razinama buke u sredini u kojoj ljudi rade i borave, http://narodne-novine.nn.hr/ (20 Feb. 2009)

[11] Escobar, M. T., Aguarón, J. and Moreno-Jiménez, J.M.: A note on AHP group consistency for the row geometric mean priorization procedure, European Journal of Operational Research, Vol. 153, No. 2., 2004

[12] Teichgräber, W.: Die Bedeutung der Geschwindigkeit für die Verkehrssicherheit. Zeitschrift für Verkehrssicherheit 29, 2, pp. 53-63, 1983

[13] Walz, F.H., Hoefliger, M., FehImann, W.: Speed limit reduction from 60 to $50 \mathrm{~km} / \mathrm{h}$ and pedestrian injuries, In: Proceedings of the 27th Stapp Car Crash Conference with International Research Committee on the Biokinetics of Impact (IRCOBI), pp. 277-285, 1983

[14] Ashton, S.J., Pedder, J.B., Mackay, G.M.: Pedestrian Injuries and the Car Exterior, University of Birmingham, Dept. of Transportation and Environmental Planning, 1977

[15] Campbell, B.C.: Die Verkehrsmenge als Kriterium für die Notwendigkeit von Fussgängerstreifen, Internationale Studienwoche für Strassenverkhrstechnik in Stresa 1956., Herausgeber: allgemeiner Deutscher Automobil-Club e. V., Munich, 1956

[16] Pasanen, E.: Driving speeds and pedestrian safety; a mathematical model, Helsinki University of Technology, Transport Engineering, Publication 77, Helsinki, 1992

[17] Yaksich, S.J.: Pedestrians with milage: A study of elderly pedestrian accidents in St. Petersburg, Florida, American Automobile Association, Washington D.C., 1964

[18] Cuerden, R., Richards, D., Hill, J.: Pedestrians and their survivability at different impact Speeds, In: Proceedings of the 20th International Technical Conference on the Enhanced Safety of Vehicles, Lyon, France, Paper No. 07-0440, 2007

[19] Hannawald, L., Kauer, F.: Equal effectiveness study on pedestrian protection, Technische Universität Dresden, Dresden, 2004

[20] Davis, G.A.: Relating severity of pedestrian injury to impact speed in vehicle pedestrian crashes: Simple 
threshold model, Transportation research record, National Research Council, Washington, D.C., No. 1773, pp. 108-113, 2001

[21] Oh, C., Kang, Y.S., Kim, W.: Development of probabilistic pedestrian fatality model for characterizing pedestrian-vehicle collision, IJAT 9, The Korean Society of Automotive Engineers, Volume 9, No. 2, pp. 191-196, 2008

[22] Department of Transportation (United Kingdom): Killing Speed and Saving Lives, As reported in Oregon Department of Transportation, Oregon Bicycle and Pedestrian Plan, Oregon, 1995

[23] Šimunović, Lj., Bošnjak, I., Mandžuka, S.: Intelligent Transport Systems and Pedestrian Traffic, Promet Traffic\&Transportation, Scientific Journal on Traffic and Transportation Research. 21 (2009), 2; pp. 141-152.
[24] Bovy, H.: Walking and cycling, EDI - World Bank, 1976.

[25] Javorović, B.: Defendologija, IPROZ, Zagreb, 2002

[26] Kacian, N.: Osnove sigurnosti, IPROZ, Zagreb, 2000

[27] Буга, П.Г.; Щелков, Ю.А.: Органиэацияа пешоходного Авижения в городах, Москва, 1980.

[28] Cvitanić, D.: Prometna tehnika, Građevinsko-arhitektonski fakultet, University of Split, lectures, Split, 2007

[29] Jelčić, I.: Medicina prometa, Multigraf, Zagreb, 1985

[30] European Commission: Green Paper - Future Noise Policy, Brussels, 1996

[31] http://www.expertchoice.com/academic-program/ (10 Feb. 2009)

[32] http://www.hak.hr/novosti/vijesti-iz-hak-a/eurotestpjesacki-prijelazi-2008.aspx (12 Feb. 2009)

[33] http://www.dzs.hr/default.hr/ (22 Feb. 2009) 